\title{
ע Metsäkoneyrittäjien ja -kuljettajien työkuormituksesta palautuminen ja työkyky työn muutoksessa
}

Riittämätön psykologinen palautuminen työkuormituksesta on työn muutoksesta nouseva työkykyhaaste. Tässä tutkimuksessa tarkastellaan psykologisen palautumisen yhteyttä koettuun työkykyyn ja sairauspoissaoloihin sekä työn vaatimuksiin ja voimavaroihin. Psykologinen palautuminen on työntekijän kokemus palautumisesta ja kokemus siitä, että pystyy jatkamaan hänelle osoitetuissa työtehtävissä.

Tutkimuskyselyyn vastasi vuonna 2018 yhteensä 322 keskimäärin 46-vuotiasta (vaihteluväli 2I-77 vuotta) metsäkoneyrittäjää ja -kuljettajaa eri puolelta Suomea. Työn vaatimusten ja voimavarojen yhteyttä psykologiseen palautumiseen selvitettiin työn vaatimukset ja voimavarat -mallin viitekehyksessä. Menetelminä käytettiin Mann-Whitney U-testiä ja logistista regressioanalyysiä. Puolet tutkimukseen osallistuneista palautui rïttämättömästi päivittäisestä työkuormituksesta. Riittämätön palautuminen oli yhteydessä heikentyneeseen työkykyyn. Riittävästi palautuneilla työkykypistemäärän keskiarvo oli 8,3 (asteikolla 0-10) ja riittämättömästi palautuneilla 6,2. Sairauspoissaolopäiviä oli riittävästi palautuneilla vuodessa keskimäärin 2,7 ja riittämättömästi palautuneilla 10,2 työpäivää. Työn hyvä organisointi ja vaatimusten hallinta sekä vahvat työn voimavarat esimerkiksi työn varmuus ja työn merkityksellisyyden kokemus lisäsivät riittävän palautumisen todennäköisyyttä.

Tämä tutkimus tukee näkemystä, että työn vaatimusten hallinta ja samanaikainen työn voimavaroista huolehtiminen sekä työn kehittäminen ovat palautumista ja työntekijöiden työkykyä tukevia tekijöitä, joihin voidaan ennakoivalla johtamisella vaikuttaa ja samalla tukea yrityksen tavoitteiden saavuttamista muuttuvassa kilpailuympäristössä.

ASIASANAT: työkyky, palautuminen, työn vaatimukset, työn voimavarat

HANNU PURSIO, ANNA SIUKOLA, HEINI HUHTALA, CLAS-HÅKAN NYGARD

\section{YDINASIAT}

- Riittävä psykologinen palautuminen ja irrottautuminen työstä on työelämän ajankohtainen työkykyhaaste.

- Informaatioteknologia on lisännyt puunkorjuutyön kognitiivista kuormittavuutta ja psykologisen palautumisen tarvetta.

- Työpaikalla tapahtuva työn vaatimusten ja voimavarojen hallinta tukee riittävää palautumista ja työkykyä.

- Työkykytutkimuksen keskiössä ovat työelämän muutosten työkykyvaikutusten tunnistaminen sekä ennakointi.

\section{JOHDANTO}

Metsätoimialan rakennemuutos on osa globaalin kilpailuympäristön muutosta, jossa yritykset uudistavat organisaatioitaan vastaamaan kilpailun vaatimuksia. Metsäteollisuuden strategiset ratkaisut ovat tarkoittaneet toiminnan uudelleen organisointia ja toimialarationalisointia sekä investointeja korkeamman jalostusarvon tuotteiden kehittämiseen. Sähköisen viestinnän kasvu on vähentänyt paino- ja kirjoituspaperituotteiden kulutusta Pohjois-Amerikassa ja Euroopassa. Metsäteollisuusyritykset ovat investoineet kasvaville markkinoille lähelle kulutusta ja asiakkaita kehit- 
tyvien talouksien maihin Aasiaan ja Etelä-Amerikkaan. Paperi- ja kartonkiteollisuutta on siirtynyt erityisesti Aasiaan, jossa pehmopaperin ja pakkauskartongin kysyntä kasvaa. Aasia on myös selluteollisuuden kasvava vientialue. (1-3.)

Metsäteollisuus on organisoinut myös puunkorjuuta uudelleen. Operatiivinen laajavastuinen puunkorjuu on siirtynyt metsäteollisuuden yrityksiltä itsenäisille metsäpalveluyrityksille. $\mathrm{Ny}$ kyaikainen puunkorjuu on palveluliiketoimintaa. (4.) Työprosesseja ohjaa mobiili digitaalinen informaatiovirta. Tämä tarkoittaa digitaalista hakkuuprosessin hallintaa, suunnittelua ja johtamista. Puunkorjuukoneet ovat internetin välityksellä reaaliaikaisesti yhteydessä metsäteollisuuden tietojärjestelmiin. Kuljettaja saa koneen järjestelmään hakkuuohjelmat, informaatiota työn tilaajista ja tiedot korjuualueen puutavaralajeista. Korjattavan puun mitta- ja laatuvaatimukset sekä metsäasiantuntijoiden työohjeet siirtyvät digitaalisesti metsäkoneiden järjestelmiin. Vastaavasti toteutuneet hakkuutiedot siirtyvät verkkoyhteyden avulla reaaliaikaisesti metsäkoneilta kuljetusyritysten ja metsäteollisuuden tietojärjestelmiin, joita metsäkoneen järjestelmät päivittävät. Metsäkoneet kehittyvät yhä enemmän itsenäisesti toimiviksi osiksi älykästä teollisen internetin verkkoa. (5-8.)

Muutos on merkinnyt sekä korjuutyön teknologista että sisällöllistä uudistumista. Työn sosiotekniset muutokset ovat edellyttäneet metsäkoneyrittäjien ja työntekijöiden sopeutumista sisällöllisesti ja organisatorisesti uuteen toimintaympäristöön. (1,4-7,9-12.) Laajavastuinen puunkorjuutyö tarkoittaa työn itsenäistä suunnittelua, laadunvalvontaa, organisointia ja digitaalisen informaatiovirran reaaliaikaista hallintaa sekä kykyä itsenäiseen operatiiviseen päätöksentekoon. Tämä kehitys on tarkoittanut työn subjektivoitumista. Vastuut ja työn vaatimukset ovat lisääntyneet sekä metsäkoneyrittäjillä, että -kuljettajilla (10.) Työn subjektivoituminen on merkinnyt yrityksen tuloksellinen toiminnan ja suorituskyvyn sitoutumista ammattitaitoisiin henkilöihin. Kriittistä on työntekijöiden motivaatio ja kyky tehdä työtä sekä mukautua koneellisen puunkorjuutyön sosiotekniseen muutokseen. (11,13-20.)

Digitalisaatio on yhteiskunnallinen ja työelämää muuttava prosessi, joka näkyy myös puunkorjuutyön työtapojen muutoksena. Tavoitteena on yrityksen suorituskyvyn ja työn tehokkuuden merkittävä parantaminen. Se muuttaa monitasoisesti yrityksen tapaa organisoida operatiivista toimintaa ja työn sisältöjä. Nykyaikaisessa puunkorjuutyössä vaativa reaaliaikainen digitaalisen informaationvirran hallinta on muuttanut työn kuormittavuuden luonnetta. Työstä on tullut henkisesti ja kognitiivisesti kuormittavaa. (6,12, 21-25.) Perustellusti voidaan työkuormituksesta palautumista pitää nykyaikaisessa digitaalisesti ohjatussa puunkorjuutyössä sekä yrityksen menestystekijänä, että työntekijöiden työhyvinvoinnin edellytyksenä (6).

Työkuormituksesta palautuminen on psykofysiologinen elpymisprosessi (26). Siitä voidaan erottaa sekä psykologinen palautuminen, omakohtainen kokemus (27), että fysiologinen palautuminen, jossa ihmisen elimistön fysiologiset toiminnat palautuvat stressitilasta lepotilaan (28). Palautumisessa olennaista on se, että työntekijä ehtii palautua päivittäisestä työkuormituksesta ennen kuin altistuu uudelleen työn vaatimuksille ja kuormitustekijöille. Psykologinen palautuminen on työtekijän henkilökohtainen kokemus siitä, että voimavarat ovat täydentyneet ja palautuneet ja pystyy edelleen suoriutumaan työn vaatimuksista ja omaan työhön kuuluvista työtehtävistä. $(27,29,30$.) Fysiologinen palautuminen voidaan todeta autonomisen hermoston aiheuttamia fysiologisia ilmiöitä rekisteröimällä. Mittaamalla esimerkiksi verenpaine, sydämen syke tai sykevälivaihtelu. (28.) Psykologinen ja fysiologinen palautuminen eroavat myös palautumismekanismien suhteen. Psykologinen irrottautuminen työstä on keskeinen psykologisen palautumisen edellytys. Fysiologista palautumista edistävät mm. terveelliset elämäntavat ja vapaa-ajan liikunta. Palautuminen on mahdollista sen jälkeen, kun työn vaatimuksiin ei tarvitse vastata.

Työn ominaispiirteet, voimavarat ja vaatimukset ovat keskeisessä asemassa tarkasteltaessa työkuormituksesta palautumista $(27,31,32)$. Työn vaatimukset ja voimavarat -mallin mukaisesti työssä on voimavaroja, jotka tukevat palautumista. Voimavarat tasapainottavat ja puskuroivat työn vaatimusten tuottamaa kuormittumista ja mahdollistavat työn tavoitteiden saavuttamisen. (33-36.) Tällaisia voimavaroja ovat esim. vaikutusmahdollisuudet omaan työhön, työn varmuus, palaute työsuorituksesta ja työtovereiden sekä esimiehen taholta saatu sosiaalinen 


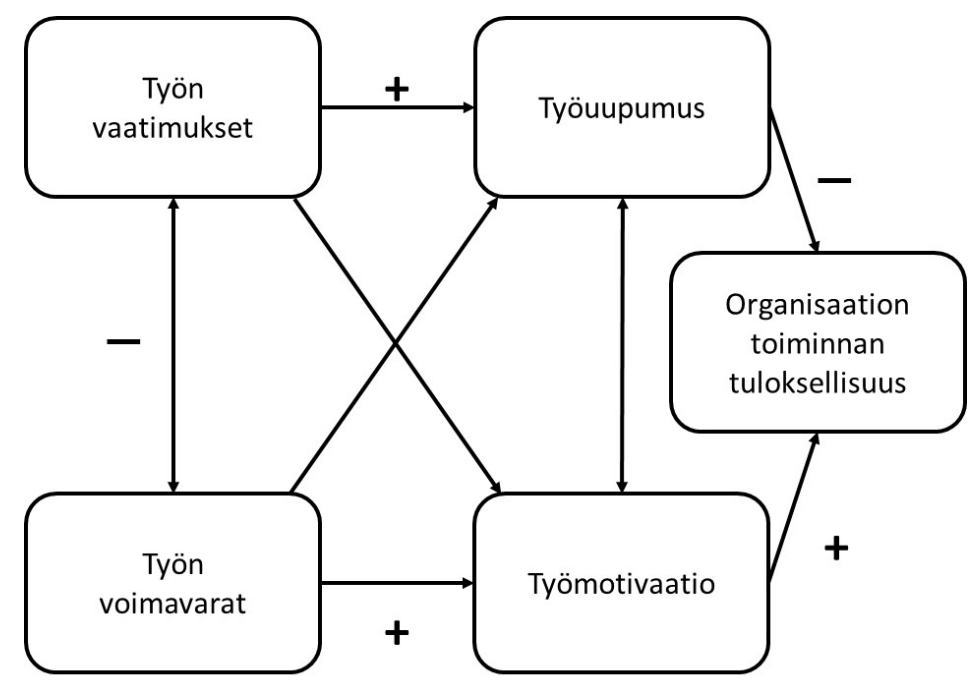

Kuvio 1. Työn vaatimukset ja voimavarat -malli (mukaillen Bakker \& Demerouti 2007).

tuki. Työn vaatimuksia ovat mm. työn aikapaine, työn määrällinen ylikuormitus, työn vaativuus ja vastuut, jotka edellyttävät fyysistä tai henkistä ponnistelua työn suorittamiseksi. (27,31-37.) Kuvio 1.

Riittävä palautuminen estää kuormituksen kasautumisen, voimavarojen ehtymisen ja työkyvyn heikentymisen $(14,28,38-41)$. Metsäteollisuudessa tehdyissä tutkimuksissa on raportoitu riittämättömän palautumisen yhteydestä myöhemmin psykosomaattisiin oireisiin, lisääntyneisiin sairauspoissaoloihin ja uupumusasteiseen väsymykseen ja mm. kohonneeseen tapaturmariskiin (42). Tutkimus rekka-autonkuljettajien palautumisen tarpeesta osoittaa yhteyden kohonneeseen sairauspoissaoloriskiin (43).

Riittävä palautuminen on työkyvyn, työhyvinvoinnin, jaksamisen ja suorituskyvyn edellytys työn vaatimusten ja sisällön muutoksessa (44-46). Systemaattinen palautumisen tukeminen yrityksen toimenpitein on strateginen prosessi. Tällöin johtamisen keinoin varmistetaan henkilöstön työkyvyn ja työhyvinvoinnin edellytykset sekä yrityksen suorituskyky muuttuvassa kilpailuympäristössä. (45,47-51.)

Tämän tutkimuksen tavoitteena oli selvittää metsäkoneyrittäjien ja metsäkoneenkuljettajien psykologista palautumista (palautumisen kokemus) työkuormituksesta ja palautumisen yhteyttä koettuun työkykyyn sekä sairauspoissaoloihin. Tavoitteena oli lisäksi tutkia puunkorjuutyön voimavarojen ja vaatimusten yhteyttä työkuormituksesta palautumiseen.

\section{TUTKIMUSAINEISTO JA MENETELMÄT}

Tutkimus perustui vuonna 2018 toteutettuun sähköiseen kyselytutkimukseen metsäkoneyrittäjille (yrittäjä) ja metsäkoneenkuljettajille (kuljettaja), jotka vastasivat anonyymisti. Kysely lähetettiin 960 yrittäjälle ja 890 kuljettajalle. Yrittäjien yhteystiedot saatiin Koneyrittäjien liiton jäsenrekisteristä ja kuljettajien yhteystiedot Puuliiton (nyk. Teollisuusliitto) jäsenrekisteristä. Kysely lähetettiin kaikille jäsenrekisrekistereissä olleille yrittäjille ja kuljettajille ja tutkimukseen otettiin mukaan kaikki vastanneet. Tutkimukseen osallistui 322 henkilöä, joista metsäkoneyrittäjiä oli $27 \%$ $(\mathrm{n}=87)$ ja metsäkoneenkuljettajia $73 \%(\mathrm{n}=235)$. Yrityskoon mukaan 1-9 hlön yrityksistä oli 53 yrittäjää ja 111 kuljettajaa ja vastaavasti 10 20 hlön yrityksistä oli 34 yrittäjää ja 124 kuljettajaa.

Tutkimuksen vastausprosentti oli 17. Metsäkoneenkuljettajista 18-30-vuotiaat ja yli 50-vuotiaat olivat jonkin verran aliedustettuna perusjoukkoon (vuoden 2020 tilasto) verrattuna. Tutkimukseen osallistuneiden yritysten edustavuutta tarkasteltiin vertaamalla alueellista jakaumaa (15\% Etelä-Suomi, $29 \%$ Länsi-Suomi, $32 \%$ Itä-Suomi ja $25 \%$ Pohjois-Suomi) vuoden 2018 teollisuuspuun vastaavien alueiden hakkuumääriin. Tutkimuksessa mukana olevien yritysten ja 
henkilöstön alueellinen sijoittuminen edusti lähes samassa suhteessa teollisuuspuun hakkuiden valtakunnallisia painopistealueita ja antaa näin riittävän kokonaiskuvan puunkorjuutoimialasta.

Vastausaktiivisuuden nostamiseksi käytettiin useita eri keinoja. Sähköisillä "karhukirjeillä" varmistettiin kaikkien osallistumismahdollisuus. Tutkimuksesta kirjoitettiin ja tiedotettiin Puuliiton (nyk. Teollisuusliitto) ja Koneyrittäjien liiton ammattilehdissä. Tutkijat olivat mukana valtakunnallisissa Metsäkonealan ja Puuliiton tilaisuuksissa, joissa oli myös tutkimuslomakkeiden täyttömahdollisuus. Yrittäjien aktivoimiseksi tutkijat olivat yhteydessä Metsäkoneyrittäjien paikallisosastojen puheenjohtajiin.
Säännöllistä päivätyötä (6-18,00 välillä) teki $39,8 \%$ ja säännöllistä kaksivuorotyötä (6-23,00välillä) 44,3\% vastaajista. Muussa työaikamuodossa työskenteli $12,5 \%$ vastaajista $(\mathrm{n}=322)$. Kokonaistyöaika/ vko. /vastaajien prosentti osuus oli 40h. /vko. 20,2 \%, 41-50h./vko. 58,7 \% ja yli 50h./vko. 18,7 \%. Aikapainetta työssään koki usein 70,5\% ja silloin tällöin tai harvoin 29,5\% vastaajista. Tutkimukseen osallistuneista yrittäjistä $36 \%(n=87)$ ja kuljettajista $67 \% \quad(n=235)$ oli suorittanut metsäalan tutkinnon. Työssä oppineita oli yrittäjistä noin puolet ja kuljettajista noin neljännes.

Taulukko1. Tutkimukseen osallistuneiden taustatietoja

\begin{tabular}{lll}
\hline Taustatiedot & Keskiarvo & Vaihteluväli \\
\hline Kaikkien osallistuneiden keski-ikä (vuotta) & 46,1 & $21-77$ \\
Yrittäjien keski-ikä (vuotta) & 49,4 & $28-77$ \\
Kuljettajien keski-ikä (vuotta) & 44,8 & $21-66$ \\
Kokonaistyöaika yrittäjät (tuntia/ viikko) & 56 & $20-85$ \\
Kokonaistyöaika kuljettajat (tuntia/ viikko) & 45 & $30-70$ \\
Metsäalan työkokemus yrittäjät (vuotta) & 26 & $1-55$ \\
Metsäalan työkokemus kuljettajat (vuotta) & 20 & $1-50$ \\
\hline
\end{tabular}

\section{MENETELMÄT}

Metsäkoneyrittäjiä ja metsäkoneenkuljettajia tarkasteltiin erikseen työn organisatorisen aseman vuoksi. Laajavastuisessa puunkorjuussa yrittäjä on yrityksessä tulosvastuullinen ja vastaa työn organisoinnista ja on esimiesasemassa kuljettajaan nähden. Myös metsäkoneenkuljettajilla on tulos- ja laatuvastuu työn itsenäisyyden ja työn vahvan subjektivoitumisen seurauksena sekä ympäristölainsäädännön velvoitteiden vuoksi. Työpositioiden erillinen tarkastelu tuo esille organisaatioasemaan ja palautumiseen yhteydessä olevat samankaltaisuudet sekä erot. Havainnoilla on merkitystä puunkorjuutyön kehittämisen ja johtamisen näkökulmasta. Molempia ammattiryhmiä tarkasteltiin myös yhdessä yrityksen toiminnan kokonaiskuvan hahmottamiseksi.

Tutkimuksessa palautumista kysyttiin yhdellä kysymyksellä; ”Kuinka hyvin koet yleensä palautuvasi työsi aiheuttamasta kuormituksesta työpäivän / työvuoron jälkeen” (palautumisen arvio). Palautumisen arviointi tapahtui asteikolla 1-5 (1=hyvin, 5=huonosti) ja luokiteltiin kaksiluokkaiseksi $1-2=$ riittävä palautuminen ja 3-5= riittämätön palautuminen. Tämä yhden kysymyksen mittari on arvioitu päteväksi ja samalla sillä on raportoitu vahva yhteys palautumisen tarpeeseen. (52.)

Koettua työkykyä selvitettiin kahdella yksilötutkaan sisältyvällä kysymyksellä. 1.”Minkä pistemäärän annat työkyvyllesi tällä hetkellä verrattuna elinikäiseen parhaimpaan asteikolla (0-10)?” Pistemäärä luokiteltiin kahteen luokkaan $0-7=$ työkyky heikentynyt, 8-10 hyvä työkyky. 2. "Pystytkö työskentelemään nykyisessä tehtävässäsi terveytesi puolesta kahden vuoden kuluttua asteikolla (0-10)?” Pistemäärä luokiteltiin myös tässä kahteen luokkaan 0-7= työkyky heikentynyt / en pysty, 8-10 hyvä työkyky/ melko varmasti. (53.) Tutkimuksessa käytetyt yksilötutkan työkykykysymykset asteikolla (0-10) luokiteltiin kahteen luokkaan, 0-7= työkyky heikentynyt ja 8-10 hyvä työkyky, aikaisemmissa tutkimuksissa käytettyjen luokittelujen perusteella. $(54,55$.) Yksilötutkan työkykyä kuvaavat kysymykset on arvioitu päteviksi tarkasteltaessa subjektiivista työkykyä suhteessa työhön (5659). 
Sairauspoissaolojen määrä oli analyysissä jatkuva muuttuja ja sitä kartoitettiin kysymyksellä: "Montako työpäivää olet ollut poissa töistä oman sairauden / tapaturman takia viimeksi kuluneen vuoden (12kk) aikana?”

Psykologista palautumista tarkasteltiin suhteessa työn vaatimuksiin ja voimavaroihin. $\mathrm{Pa}$ lautumista selittäviksi muuttujiksi valittiin työn vaatimuksia ja voimavaroja, joita on aikaisemmissa tutkimuksissa käytetty psykologisen palautumisen tarkasteluun. (41,60.) Tässä tutkimuksessa työn vaatimuksia olivat, työn aikapaine, henkinen kuormitus, työn organisointi, työaikajärjestelyt ja tietojärjestelmien hallinta. Voimavaroiksi valittiin, työn varmuus / jatkuvuus, työtovereiden sosiaalinen tuki, vaikutusmahdollisuudet työhön ja oikeudenmukaisuuden kokemus työssä. Lisäksi voimavaroiksi otettiin työn merkityksellisyyden kokemus ja subjektiivisten yksilöllisten voimavarojen suhde työn vaatimuksiin. (33,41,61-64.)

Riittävästi ja riittämättömästi palautuneiden yrittäjien ja kuljettajien työkyvyn ja sairauspoissaolojen eron merkitsevyyttä tarkasteltiin MannWhitneyn U-testillä. Palautumista selittävien työn voimavara- ja kuormitustekijöiden vaikutusta arvioitiin logistisella regressioanalyysillä. Tätä analyysiä varten palautuminen muutettiin 0/1luokiksi $0=$ palautuminen riittämätöntä ja $1=$ riittävä palautuminen. Palautumista selittävät muuttujat luokiteltiin kaksiluokkaisiksi. Yksit- täiset puuttuvat havainnot korvattiin muuttujan ryhmäkeskiarvolla ja -mediaanilla aineiston määrän maksimoimiseksi. Aineiston analysoinnissa käytettiin SPSS 25.0-ohjelmaa.

\section{TULOKSET}

Tutkimukseen osallistuneista metsäkoneyrittäjistä ja metsäkoneenkuljettajista noin puolet arvioi palautuvansa riittävästi päivittäisestä työkuormituksesta ja vastaavasti puolet arvioi, että palautuminen oli riittämätöntä (Taulukko 2.). Työn aikapainetta koki usein yrittäjistä 70,1\% (n=87) ja kuljettajista 70,6 \% (n=235). Yrittäjistä 56,3\% ja kuljettajista $60,9 \%$ koki kiireen lisääntyneen työssään. Yrittäjistä noin $53 \%$ ja kuljettajista $41 \%$ koki toimialan kilpailun kiristymisen aiheuttaneet paljon tulevaisuuden epävarmuutta. Yrittäjistä 62,1\% ja kuljettajista 54,1\% koki myös epävarmuutta työn jatkuvuudesta ja ennustettavuudesta. Noin puolet kaikista vastanneista käytti työssään useita tietojärjestelmiä ja noin 2/3 koki työn osaamisvaatimusten lisääntyneen tietojärjestelmiin liittyen. Stressiä koki yrittäjistä $26,4 \%$ ja kuljettajista 20,4\%. Henkisen kuormittumisen koki lisääntyneen työssään viimeisen kahden vuoden aikana 60,9\% yrittäjistä $(\mathrm{n}=87)$ ja $57,4 \%$ kuljettajista $(\mathrm{n}=235)$. Yrittäjistä $89,6 \%$ ja kuljettajista 76,6 \% koki työn fyysisen kuormittavuuden vähentyneen tai pysyneen ennallaan samalla aikavälillä.

Taulukko 2. Yrittäjien ja metsäkoneenkuljettajien arvio työn aiheuttamasta kuormituksesta palautumisesta työpäivän / työvuoron jälkeen

\begin{tabular}{lcccccc}
\hline & \multicolumn{2}{c}{ Yrittäjä } & $=87$ & \multicolumn{2}{c}{ Metsäkoneenkuljettaja n=235 } & Kaikki n=322 \\
\hline Palautumisen arvio & $\%$ & $\mathrm{n}$ & $\%$ & $\mathrm{n}$ & $\%$ & $\mathrm{n}$ \\
\hline Riittävä palautuminen (arvio 1-2) & 49,4 & 43 & 52,3 & 123 & 51,6 & 166 \\
\hline Riittämätön palautuminen (arvio 3-5) & 50,6 & 44 & 47,7 & 112 & 48,4 & 156 \\
\hline
\end{tabular}

Palautumista on arvioitu asteikolla 1-5 (1= hyvin, 5=huonosti).

Taulukossa 3. yrittäjien ja kuljettajien palautumisen yhteyttä työkykyyn tarkasteltiin kahdella työkykyindikaattorilla. Työkykyä verrattiin elinikäiseen parhaimpaan ja vastaajat arvioivat myös tutkimushetken perusteella työkykyään nykyisessä työssä kahden vuoden kuluttua. Tulosten perusteella riittäväksi palautumisensa kokeneilla yrittäjillä ja kuljettajilla koettu työkyky oli parempi verrattuna riittämättömästi palautuneiden työkykyyn. em. kahdella työkykyindikaattorilla arvioituna. Koko aineistossa riittäväksi palautumisensa kokeneilla oli paremmat arviot työkyvystään $(\mathrm{ka} \mathrm{8,3)}$ kuin riittämättömäksi palautumisensa kokeneilla (ka 6,2), kun työkykyä verrattiin elinikäiseen parhaimpaan. Taulukon 3. havaintojen perusteella riittävä psykologinen palautuminen oli yhteydessä työpositiosta riippumatta parempaan työkykyyn. Samoin sairauspoissaolot viimeisen $12 \mathrm{kk}$. aikana olivat vähäisempiä. 
Taulukko 3. Palautumisen yhteys työkykyyn verrattuna elinikäiseen parhaimpaan ja työkykyyn nykyisessä työssä $2 \mathrm{v}$. kuluttua sekä yhteys sairauspoissaolopäiviin viimeisen $12 \mathrm{kk}$. aikana

\begin{tabular}{|c|c|c|c|c|c|}
\hline & \multicolumn{2}{|c|}{ Riittävä palautuminen } & \multicolumn{3}{|c|}{ Riittämätön palautuminen } \\
\hline $\begin{array}{l}\text { Työkyky verrattuna elinikäiseen parhaimpaan } \\
\text { (asteikolla } 0-10 \text { ) }\end{array}$ & $\mathrm{ka}$ & sd & $\mathrm{ka}$ & sd & $\mathrm{p}$ \\
\hline Yrittäjä $n=87$ & 8,1 & 1,4 & 6,0 & 2,3 & $<0,001$ \\
\hline Metsäkoneenkuljettaja $n=235$ & 8,4 & 1,6 & 6,2 & 2,2 & $<0,001$ \\
\hline Kaikki $n=322$ & 8,3 & 1.5 & 6,2 & 2,2 & $<0,001$ \\
\hline \multicolumn{6}{|l|}{ Työkyky 2v. kuluttua (asteikolla 0-10) } \\
\hline Yrittäjä n=87 & 9,2 & 1,0 & 7,5 & 2,6 & $<0,001$ \\
\hline Metsäkoneenkuljettaja $n=235$ & 9,2 & 1,3 & 7,0 & 2,6 & $<0,001$ \\
\hline Kaikki n=322 & 9,2 & 1,2 & 7,2 & 2,6 & $<0,001$ \\
\hline \multicolumn{6}{|l|}{$\begin{array}{l}\text { Sairauspoissaolot (työpäivinä viimeisen 12kk. } \\
\text { Aikana) }\end{array}$} \\
\hline Yrittäjä n=87 & 1,2 & 2,1 & 9,9 & 19,9 & 0,001 \\
\hline Metsäkoneenkuljettaja $n=235$ & 3,2 & 8,5 & 10,3 & 35,7 & 0,001 \\
\hline Kaikki $n=322$ & 2,7 & 7,4 & 10,2 & 32,0 & $<0,001$ \\
\hline
\end{tabular}

Tilastollinen merkitsevyys on määritetty Mann-Whitneyn U -testillä.

Taulukoissa 4. ja 5. on raportoitu logistisen regressioanalyysin tulokset, joissa tarkasteltiin työn vaatimusten ja voimavarojen yhteyttä riittävään psykologiseen palautumiseen. Malli ennustaa sekä yrittäjien että kuljettajien riittävää palautumista. Työn vaatimuksia tarkasteltaessa koko aineistossa monimuuttujamallin selitysaste oli $25 \%$. Selitysaste oli yrittäjillä $27 \%$ ja kuljetta- jilla $26 \%$. Koko aineistossa monimuuttujamallin työn vaatimukset, hyvä työn organisointi, vähäinen aikapaine työssä ja vähentynyt työn henkinen rasittavuus sekä joustavat työaikajärjestelyt olivat yhteydessä riittävään palautumiseen. Yhden selittäjän mallissa kaikki muut työn vaatimusmuuttujat paitsi yrittäjillä tietojärjestelmien hallinta olivat yhteydessä riittävään palautumiseen.

Taulukko 4. Työn vaatimusten yhteydet riittävään työkuormituksesta palautumiseen

\begin{tabular}{|c|c|c|c|c|}
\hline \multirow[b]{2}{*}{ Työn vaatimukset /Yrittäjät } & \multicolumn{2}{|c|}{ Yhden selittäjän malli } & \multicolumn{2}{|c|}{ Monimuuttujamalli } \\
\hline & OR & $95 \% \mathrm{lv}$ & OR & $95 \% \mathrm{lv}$ \\
\hline Harvoin aikapainetta työssä & 2,47 (ns.) & $0,95-6,42$ & 1,66 (ns.) & $0,50-5,50$ \\
\hline Hyvä työn organisointi & $3,19 *$ & $1,10-9,25$ & 2,22 (ns.) & $0,63-7,87$ \\
\hline Hyvä tietojärjestelmien hallinta & 0,72 (ns.) & $0,31-1,68$ & 0,54 (ns.) & $0,20-1,43$ \\
\hline Vähentynyt työn henk. rasittavuus & $3,45 * *$ & $1,39-8,56$ & 2,06(ns.) & $0,70-6,00$ \\
\hline Hyvin sopivat työaikajärjestelyt & $11,71 * *$ & $2,49-55,00$ & $8,50 * *$ & $1,67-43,12$ \\
\hline Työn vaatimukset / Kuljettajat & OR & $95 \% \mathrm{lv}$ & OR & $95 \% \mathrm{lv}$ \\
\hline Harvoin aikapainetta työssä & $3,05 * * *$ & $1,67-5,57$ & 1,75 (ns.) & $0,88-3,49$ \\
\hline Hyvä työn organisointi & $3,09 * * *$ & $1,81-5,28$ & $2,14 *$ & $1,18-3,89$ \\
\hline Hyvä tietojärjestelmien hallinta & $4,41 * *$ & $1,64-4,87$ & 2,81 (ns.) & $0,92-8,56$ \\
\hline Vähentynyt työn henk. rasittavuus & $3,61 * * *$ & $2,08-6,26$ & $1,92 *$ & $1,02-3,63$ \\
\hline Hyvin sopivat työaikajärjestelyt & $3,89 * * *$ & $2,05-7,36$ & $2,74 * *$ & $1,37-5,49$ \\
\hline Työn vaatimukset / Kaikki yhteensä & OR & $95 \%$ lv & OR & $95 \% \mathrm{lv}$ \\
\hline Harvoin aikapainetta työssä & $2,89 * * *$ & $1,74-4,81$ & $1,84 *$ & $1,03-3,29$ \\
\hline Hyvä työn organisointi & $2,90 * * *$ & $1,83-4,62$ & $1,98 * *$ & $1,18-3,32$ \\
\hline Hyvä tietojärjestelmien hallinta & $1,91 * *$ & $1,22-2,98$ & 1,52 (ns.) & $0,92-2,51$ \\
\hline Vähentynyt työn henk. rasittavuus & $3,57 * * *$ & $2,23-5,72$ & $2,15 * *$ & $1,26-3,67$ \\
\hline Hyvin sopivat työaikajärjestelyt & $4,70 * * *$ & $2,64-8,38$ & $3,20 * * *$ & $1,73-5,93$ \\
\hline
\end{tabular}

$(\mathrm{OR}=$ ristitulosuhde ja $95 \% \mathrm{lv}=$ luottamusväli) $* * \mathrm{p}<0,001, * * \mathrm{p}<0,01, * \mathrm{p}<0,05 \mathrm{~ns}=$ ei ole tilastollisesti merkitsevä Referenssiluokat: Usein aikapainetta työssä, puutteellinen työn organisointi, puutteellinen tietojärjestelmien hallinta, lisääntynyt työn henkinen rasittavuus, huonosti sopivat työaikajärjestely 
Työn voimavarojen tarkastelussa monimuuttujamallin selitysaste oli koko aineistossa ja yrittäjillä oli $30 \%$ ja kuljettajilla $34 \%$. Koko aineistossa monimuuttujamallin riittävää palautumista selittäviä voimavaroja olivat työn varmuus ja jatkuvuus, työn päivittäinen merkityksellisyys ja omat henkilökohtaiset voimavarat työhön sekä oikeu- denmukaisuuden kokemus työssä. Päivittäinen työn merkityksellisyyden kokemus oli tärkeä työn voimavara riittävän psykologisen palautumisen kannalta sekä yrittäjillä, että kuljettajilla. Kuljettajilla lisäksi omat voimavarat ja oikeudenmukaisuuden kokemus osoittautuivat myös tärkeiksi riittävän palautumisen selittäjiksi.

Taulukko 5. Työn voimavarojen yhteydet riittävään työkuormituksesta palautumiseen

\begin{tabular}{|c|c|c|c|c|}
\hline \multirow[b]{2}{*}{ Työn voimavarat /Yrittäjät } & \multicolumn{2}{|c|}{ Yhden selittäjän malli } & \multicolumn{2}{|c|}{ Monimuuttujamalli } \\
\hline & OR & $95 \% \mathrm{lv}$ & OR & $95 \%$ lv \\
\hline Työn varmuus / jatkuvuus & 3,62 (ns.) & $0,91-14,43$ & 3,30 (ns.) & $0,68-16,00$ \\
\hline Työ merkityksellistä päivittäin & $3,29 * *$ & $1,36-7,94$ & $2,92 *$ & $1,05-8,10$ \\
\hline Vahva sosiaalinen tuki työssä & $6,03 *$ & $1,24-29,41$ & 3,14(ns.) & $0,51-19,22$ \\
\hline Hyvät vaikutusmahdollisuudet työhön & 0,64 (ns.) & $0,10-4,00$ & 0,17 (ns.) & $0,02-1,67$ \\
\hline Hyvät voimavarat työhön & $3,88 *$ & $1,35-11,15$ & 2,41 (ns.) & $0,68-8,52$ \\
\hline Vahva oikeudenmukaisuuden kokemus työssä & $7,69 *$ & $1,61-36,83$ & 3,35(ns.) & $0,58-19,49$ \\
\hline
\end{tabular}

\begin{tabular}{|c|c|c|c|c|}
\hline Työn voimavarat / Kuljettajat & OR & $95 \% \mathrm{lv}$ & OR & $95 \% \mathrm{lv}$ \\
\hline Työn varmuus / jatkuvuus & $2,67 * *$ & $1,35-5,31$ & 2,00(ns.) & $0,91-4,38$ \\
\hline Työ merkityksellistä päivittäin & $3,90 * *$ & $2,21-6,89$ & $2,79 * *$ & $1,45-5,33$ \\
\hline Vahva sosiaalinen tuki työssä & $2,63 * *$ & $1,33-5,22$ & 0,79 (ns.) & $0,34-1,84$ \\
\hline Hyvät vaikutusmahdollisuudet työhön & $2,97 * *$ & $1,61-5,50$ & 1,43 (ns.) & $0,70-2,93$ \\
\hline Hyvät voimavarat työhön & $4,88 * * *$ & $2,62-9,10$ & $3,79 * *$ & $1,90-7,55$ \\
\hline Vahva oikeudenmukaisuuden kokemus työssä & $5,20 * * *$ & $2,89-9,35$ & $3,38 * * *$ & $1,72-6,62$ \\
\hline Työn voimavarat / Kaikki yhteensä & OR & $95 \% \mathrm{lv}$ & OR & $95 \% \mathrm{lv}$ \\
\hline Työn varmuus / jatkuvuus & $2,86 * *$ & $1,55-5,27$ & $2,27 *$ & $1,15-4,47$ \\
\hline Työ merkityksellistä päivittäin & $3,54 * * *$ & $2,22-5,66$ & $2,56 * *$ & $1,50-4,36$ \\
\hline Vahva sosiaalinen tuki työssä & $3,02 * * *$ & $1,63-5,60$ & 1,13 (ns.) & $0,54-2,36$ \\
\hline Hyvät vaikutusmahdollisuudet työhön & $2,36 * *$ & $1,35-4,16$ & 1,00 (ns.) & $0,52-1,95$ \\
\hline Hyvät voimavarat työhön & $4,57 * * *$ & $2,68-7,81$ & $3,16 * * *$ & $1,76-5,68$ \\
\hline Vahva oikeudenmukaisuuden kokemus työssä & $4,96 * * *$ & $2,92-8,42$ & $3,05 * * *$ & $1,67-5,57$ \\
\hline
\end{tabular}

$(\mathrm{OR}=$ ristitulosuhde ja $95 \% \mathrm{lv}=$ luottamusväli) $* * * \mathrm{p}<0,001, * * \mathrm{p}<0,01, * \mathrm{p}<0,05 \mathrm{~ns}=$ ei ole tilastollisesti merkitsevä Referenssiluokat: Työn epävarmuus, työ merkityksellistä harvoin, heikko sosiaalinen tuki työssä, vähäiset vaikutusmahdollisuudet työhön, puutteelliset voimavarat työhön, heikko oikeudenmukaisuuden kokemus työssä.

\section{POHDINTA}

Tämä tutkimus osoitti, että riittävä psykologinen palautuminen (subjektiivinen palautumisen kokemus) päivittäisestä työkuormituksesta oli yhteydessä hyvään työkykyyn sekä metsäkoneyrittäjillä että -kuljettajilla. Riittämätön palautuminen oli vastaavasti yhteydessä heikentyneeseen työkykyyn ja korkeampiin sairauspoissaololukuihin. Merkittävä havainto oli se, että nämä yhteydet olivat organisaatioasemasta riippumattomia.

Noin puolet tutkimukseen osallistuneista metsäkoneyrittäjistä ja -kuljettajista palautui riittävästi päivittäisestä työkuormituksesta. Vastaa- vasti puolella palautuminen oli riittämätöntä ja heistä $10 \%$ palautuu huonosti. Aiemman tutkimuksen mukaan mm. palvelu- ja koulutusalan ammattiryhmissä riittämättömästi palautuneiden osuus on samansuuntainen (52). Riittämättömästi palautuneilla yrittäjillä työkyvyn keskiarvo (työkyky verrattuna elinikäiseen parhaimpaan, asteikolla $0-10$ ) oli 6,0 ja kuljettajilla 6,2. Väestötasolla työssä käyvillä 30-64-vuotiailla yrittäjillä työkyvyn keskiarvo oli 8,7 ja metsätyöntekijöillä 8,1(65). Tulosten perusteella riittämättömästi palautuneilla yrittäjillä ja kuljettajilla oli heikompi työkyky, kuin vastaavan 
kuormitustason toimialojen työssä käyvillä miehillä keskimäärin. Esimerkiksi Roelen ym. (66) tutkimuksessa fyysisesti kuormittavassa rakennusalan työssä työntekijöiden ja toimihenkilöiden työkykypistemäärän keskiarvo oli korkeampi.

Tulokset vahvistivat sen, että hyvät työn voimavarat tukevat palautumista. Tärkeitä työn voimavaroja olivat, työn varmuus ja jatkuvuus, työn koettu merkityksellisyys, omat voimavarat työn suorittamiseen ja oikeudenmukaisuuden kokemus työssä. Palautumisen ja työkyvyn kannalta olennaisia ovat riittävät omat voimavarat suhteessa työn vaatimuksiin $(67,68)$. Tulosten perusteella työn vaatimuksista hyvä työn organisointi, aikapaineiden hallinta, joustavat työaikajärjestelyt ja työn henkisen rasittavuuden hallinta selittivät riittävää työkuormituksesta palautumista.

Tässä tutkimuksessa runsas puolet yrittäjistä ja kuljettajista oli kokenut työn henkisen rasittavuuden lisääntyneen. Samoin valtaosa oli kokenut työssään aikapaineita. Ylipitkät työviikot ovat työn kuormitustekijöitä, jotka vaikuttavat palautumiseen $(37,69)$. Noin 2/3:1la kokonaistyöaika oli yli 40 tuntia viikossa. Puunkorjuun tiivis logistinen ketju hakkuulta tehtaalle on lisännyt työn aikapaineita ja myös intensiteettiä (70). Aiempien tutkimusten havaintojen perusteella $(69,71)$ myös puunkorjuuyrittäjien ja kuljettajien palautumisen kannalta viikoittainen työntuntimäärä on haasteellinen.

Tutkimus paljasti merkittävän työkykyriskin puunkorjuun toimialalla. Riittämätön psykologinen palautuminen on ilmeinen työkykyriski. Tässä tutkimuksessa pääpaino oli niiden työn ominaisuuksien tarkastelussa, jotka ovat palautumista edistäviä voimavaroja ja kuormitusta aiheuttavia työn vaatimuksia. Psykologista palautumista edistäviä voimavaroja olivat omat voimavarat suhteessa tehtävään työhön, oikeudenmukaisuuden kokemus työssä ja työn merkityksellisyyden kokemus. Aiemmissa tutkimuksissa raportoidut työn voimavarat, jotka edistävät riittävää palautumista ovat pääpiirteittäin samoja $(35,36)$.

Työn vaatimukset ja voimavarat -malli (Job Demands-Resources model) oli tässä tutkimuksessa työn ominaisuuksien tarkastelun teoreettinen viitekehys $(33,34)$. Mallin lähtökohtana on kaksi perusolettamaa. Riippumatta työtehtävis- tä, ammateista tai organisaatioista voidaan työn ominaisuudet jakaa kahteen luokkaan, työn vaatimukset ja työn voimavarat $(33,35,72)$. Työn vaatimuksilla ja voimavaroilla tarkoitetaan työn fyysisiä, psyykkisiä, sosiaalisia tai organisatorisia piirteitä. Työn vaatimukset edellyttävät työntekijöiltä työssä fyysisiä, psyykkisiä, kognitiivisia tai emotionaalisia ponnisteluja esim. aikapaineet ja vastuut $(35,36)$. Työn voimavarat ovat työn ominaisuuksia, jotka vähentävät työn vaatimusten kielteisiä vaikutuksia ja mahdollistavat työn tavoitteiden saavuttamisen. Tällaisia voimavaroja ovat esim. työn jatkuvuus, työtovereiden ja esimiehen sosiaalinen tuki ja vaikutusmahdollisuudet omaan työhön. Työn vaatimukset ja voimavarat mallissa on kaksi rinnakkaista psykologista prosessia $(33,72)$. Terveyttä heikentävä prosessi, joka voi johtaa työntekijän henkisten ja fyysisten voimavarojen ehtymiseen ja terveys- ja työkykyongelmiin. Työn voimavaroihin perustuva motivaatiota ylläpitävä prosessi, joka edistää työntekijän henkistä kasvua, oppimista ja kehittymistä sekä auttavat työn tavoitteiden saavuttamisessa. Prosessit ovat yhteydessä ja vaikuttavat toisiinsa.

Puunkorjuutyö on muutoksessa, kuten koko metsätoimiala. Työtä organisoidaan vastaamaan metsäteollisuuden rakennemuutosta. Digitalisaatio muuttaa työn sisältöjä ja teknologinen kehitys muuttaa työtapoja korjuutyön ytimessä hakkuutyössä. Tässä muutoksessa myös työn kuormittavuutta ja työkyvyn tukemista on arvioitava uudella tavalla. Tässäkin tutkimuksessa esillä olleita työn voimavaroja vahvistamalla ja työtä kehittämällä voidaan lisätä työn muutoksessa organisaation suorituskykyä ja tukea henkilöstön työkuormituksesta palautumista sekä työkykyä. $(21,45$.

Kariniemen (6) tutkimus osoitti, että nykyaikaisessa puunkorjuussa, jossa digitaalisen tietovirran hallinta on olennainen osa työtä, painottuu kognitiivinen ja psyykkinen kuormitus. Samalla muutoskokemus vaikuttaa siihen, miten työstä suoriutuu (73). Laajavastuinen puunkorjuu on muuttanut erityisesti yrittäjän vastuita ja työn sisältöä, mutta samalla tavoin myös metsäkoneenkuljettajien työtä. Vastuiden ja osaamisvaatimusten laajentuminen, työn intensiteetti ja kognitiivinen kuormitus ovat työn uusia vaatimuksia. Tämä korostaa psykologisen palautuminen tärkeyttä sekä yksilön työkyvyn, että 
myös yrityksen tuloksellisen toiminnan kannalta $(6,74,75)$.

Tulosten perusteella työn voimavaroja vahvistava johtaminen on yrityksen menestymisen ja henkilöstön motivaation, sitoutumisen sekä työkyvyn kannalta keskiössä. (72, 76-79.). Tutkimuksessa huomio kiinnittyi yrittäjien ja metsäkoneenkuljettajien alempiin työkykypistemääriin verrattuna vastaaviin henkilöstöryhmiin. Keskeinen selittävä tekijä oli riittämätön työkuormituksesta palautuminen.

Työkuormituksesta palautuminen, työn vaatimukset ja voimavarat eivät ole toimintaympäristöstään irrallisia ja erillisiä ilmiötä. Palautumista tulee tarkastella yhteydessä siihen toimintaympäristöön, jossa työ tehdään. $(31,80$.) Tässä tutkimuksessa psykologinen työkuormituksesta palautuminen ja työn vaatimukset kytkeytyivät metsätoimialan rakennemuutokseen ja puunkorjuutyön sisällölliseen muutokseen. Toimintaympäristön muutokset, työn teknologinen kehitys, digitalisaatio ja laajavastuinen toimintamalli ovat muuttaneet työn vaatimuksia. Kiristynyt kilpailu, tulevaisuuden epävarmuus, henkisen kuormituksen ja vastuiden lisääntyminen sekä tietotekniikan hallinta olivat mm. puunkorjuutyön vaatimuksia, joilla oli yhteys palautumiseen.

Työkuormituksesta palautuminen on psykofysiologinen elpymisprosessi (30). Palautumisessa voidaan erottaa sekä psykologinen, että fysiologinen palautuminen. Psykologinen palautuminen on omakohtainen kokemus palautumisesta ja kokemus siitä, että pystyy edelleen jatkamaan omassa työssään. Fysiologisessa palautumisessa ihmisen elimistön fysiologiset toiminnat palautuvat stressitilasta lepotilaan. Palautumisen kannalta olennaista on se, että työntekijä ehtii palautua päivittäisestä työkuormituksesta ennen kuin altistuu uudelleen työn vaatimuksille ja kuormitustekijöille. Työstä irrottautumista on pidetty merkittävimpänä palautumiskokemuksena. $(39,47,81$.

Ratkaisu riittävään palautumiseen ja sitä kautta työkyvyn ylläpitämiseen on tätä taustaa vasten yrityksissä ja työpaikoilla. Tukemalla työkuormituksesta palautumista ja huolehtimalla työhön käytettävistä voimavaroista voidaan yrityksen toimesta välttää työn vaatimusten muodostuminen työkykyä ja yrityksen tuloksentekoa heikentäväksi poluksi. Erityisesti työn hyvä organisointi ja työn merkityksellisyyden kokemus olivat tässä niitä palautumista edistäviä tekijöitä, joihin voidaan hyvällä johtamisella vaikuttaa. $(50,54,72,78$.

\section{TUTKIMUKSEN VAHVUUDET JA RAJOITUKSET}

Tällä tutkimuksella on rajoituksia. Tutkimus oli poikkileikkaustutkimus ja antaa kuvan puunkorjuuyrittäjien ja -kuljettajien palautumisesta ja työn ominaisuuksista sekä toimintaympäristöstä tutkimusvuonna. Poikkileikkausasetelman vuoksi kausaalisuhteita ei voida avata tämän aineistojen pohjalta. Tutkimuksen keskeisin rajoitus oli alhainen kokonaisvastausprosentti (17\%). Tämä vaikuttaa havaintojen yleistettävyyteen heikentävästi. Tulos ei ole kuitenkaan poikkeuksellinen. Vastaavanlaisia tuloksia metsäalan tutkimuksista on raportoitu Suomessa ja Irlannissa $(82,83,84)$. Tutkimustulosten yleistettävyyttä tukee toisaalta vastaajien maantieteellinen tasainen suhteellinen jakauma koko Suomen alueella. Samoin aineistossa oli edustettuna puunkorjuualan kaikki toimijat, metsäkoneyrittäjät ja -kuljettajat sekä keskeiset yritysmuodot, alueyrittäjät, alihankkijat ja itsenäiset yrittäjät. Tutkimuksen yritykset ovat tasapainoisesti suhteessa teollisuuspuun alueellisiin hakkuumääriin ja edustavat puunkorjuun painopistealueita. Menetelmällisesti työn vaatimukset-voimavarat -malli tuki työn vaatimusten ja voimavarojen systemaattista tarkastelua.

Tutkimuksen eettisyys varmistettiin informoimalla tutkimukseen osallistuvia laajasti ennen tutkimusta jaetulla yleisinformaatiolla ja jokaiselle jaetulla tutkimussaatteella. Jokaiselta vastaajalta pyydettiin allekirjoituksella henkilökohtainen suostumus siihen, että kyselyn vastauksia voidaan käyttää tutkimustarkoitukseen. Tutkimusaineisto on anonyymiä ja luottamuksellista. Osallistujilla oli myös mahdollisuus kysyä tutkimukseen liittyvistä asioista. Perusteellisella informoinnilla varmistettiin, että kaikki ymmärsivät mihin antavat suostumuksensa. Tutkimuksella, jonka osahanke tämä tutkimus on, on Tampereen alueen ihmistieteiden eettisen toimikunnan puoltava lausunto 15/2016.

\section{JOHTOPÄÄTÖKSET}

Tutkimus oli yhteiskunnallisesti ajankohtainen. Tässä tutkimuksessa saatiin uutta tietoa psykologisen palautumisen merkityksestä ammattiryhmissä, joiden työtä ei perinteisesti liitetä mobiilin informaatiovirran tuottamiseen, vastaanottami- 
seen ja käsittelemiseen. Tutkimus osoitti, että psykologinen palautuminen oli yhteydessä koettuun työkykyyn. Digitalisaatio on muuttanut työtä ja työn tekemisen muotoja kaikissa työtehtävissä, myös koneellisessa puunkorjuutyössä. Digitalisaatio on lisännyt työn osaamisvaatimuksia ja kognitiivista kuormittavuutta samalla kun työn fyysinen kuormittavuus on vähentynyt. Laajavastuinen puunkorjuu on lisännyt sekä metsäkoneyrittäjän, että metsäkoneenkuljettajan työn vastuita. Työ on subjektivoitunut ja työn hyvä tulos liittyy vahvasti tekijäänsä. Työn autonomia ja osaamisvaatimukset ovat lisääntyneet. Puunkorjuutyötä organisoidaan ja johdetaan mobiilia informaatioteknologiaa hyödyntäen entistä moninaisemmin, hajautetusti ja yksilöllisemmin. Tämä on myös laajempi ajankohtainen kuva työelämän muutoksesta.

Psykologinen palautuminen ja sen tarpeen tunnistaminen sekä hallinta on työn muutoksen ajankohtainen työkykyhaaste. Tätä tukee tutkimuksen tulos, jossa noin puolet tutkimukseen osallistuneista palautui riittämättömästi. Riittämättömästi palautuneiden koettu työkyky oli merkittävästi alhaisempi ja sairauspoissaolot runsaampia kuin riittävästi palautuneiden ryhmässä. Jos riittämätöntä palautumista ei tunnisteta ajoissa, kytkeytyy tähän kehitykseen piilossa oleva uhka, joka voi johtaa vähitellen työkyvyn pitkäaikaiseen heikentymiseen ja työssä jaksamisen ongelmiin.

Tässä tutkimuksessa tarkasteltiin työkuormituksesta palautumista, työn ominaisuuksia, työn vaatimuksia ja voimavaroja, yritysten avoimen kilpailuympäristön ja työn muutoksen ympäristössä. Tässä muutoksessa yksittäiset irralliset toimenpiteet eivät enää ole riittäviä työkyvyn edistämiseen ja ylläpitämiseen. Tarvitaan erityisesti työpaikoilla toteutettavia suunnitelmallisia toimenpidekokonaisuuksia. Työn vaatimusten muutoksia ennakoivilla toimilla kehitettään työn sisältöä, osaamista ja työn organisointia. Johtamisen keinoin voidaan yritysten toimesta näihin muutoksiin vaikuttaa ja hallita työn uusia vaatimuksia ja muuttuvia kuormitustekijöitä. Työn tehokas organisointi ja työn merkityksellisyyden kokemuksen vahvistaminen ovat johtamisen keinoja, joilla voidaan tukea riittävää palautumista ja työssä suoriutumista.

Tämän tutkimuksen tulokset antavat suunnan jatkotutkimukselle, jossa tavoitteena on tunnistaa ja ennakoida työn ja työelämän muutoksien vaikutuksia työntekijöiden työkykyyn ja terveyteen. Yhteiskunnallisesta näkökulmasta työn muutos on koko ajan käynnissä ja tarvitaan erityisesti työpaikoilla toteutettuja uusia ennakoivia ratkaisuja työkyvyn ja työssä suoriutumisen tukemiseen. Psykologinen palautuminen on sekä yksilöiden, että yritysten työkykyhaaste työn vaatimusten muuttuessa ja globaalin toimintaympäristön muuttaessa työn organisointimuotoja.

\section{KIITOKSET:}

Kiitämme Työsuojelurahastoa, Metsämiesten Säätiötä ja Koneyrittäjien liittoa sekä Teollisuusliittoa (ent. Puuliitto) tutkimuksen mahdollistamisesta. Kiitos myös mukana olleille metsäkoneyrittäjille ja metsäkoneiden kuljettajille tutkimukseen osallistumisesta.

\section{RAHOITTAJAT:}

Työsuojelurahasto, Metsämiesten Säätiö

\section{KIRJOITTAJIEN KONTRIBUUTIOT:}

Pursio: Oli vastuussa käsikirjoituksen kirjoittamisesta, tilastollisten analyysien tekemisestä ja tulkinnasta sekä osallistui tutkimuksen suunnitteluun.

Siukola: Osallistui tutkimuksen suunnitteluun, aineiston keräämiseen ja artikkelin kirjoittamiseen sekä kommentoimiseen.

Huhtala: Osallistui tilastollisten analyysien ohjaamiseen ja käsikirjoituksen kommentoimiseen.

Nygård: Osallistui tutkimuksen suunnitteluun ja johtamiseen sekä on ohjannut tutkimusprosessia ja osallistui artikkelin kirjoittamiseen ja kommentoimiseen. 
Inadequate psychological recovery from one's workload is a work-ability challenge that arises from changing work. This study examines the association of psychological recovery with perceived work ability and sickness absence, as well as with job demands and resources. Psychological recovery is an employee's experience of recovery and the experience of being able to continue in his or her job.

In 2018, a total of 322 forest machine entrepreneurs and drivers from all over Finland responded to a survey. The mean age was 46 years old (range: 21-77 years old). The relationship between job demands and resources, and psychological recovery was investigated in the frame of reference of the job demands and resources model. The Mann-Whitney U-test and logistic regression analysis were used as methods. Half of the participants in the study did not recover adequately from their daily workload. Inadequate recovery was associated with impaired work ability. Those with adequate recovery had a mean work ability score of 8.3 (on a scale of $0-10$ ) and those with inadequate recovery had a mean score of 6.2. The average number of sickness absence days was 2.7 working days per year for those who recovered adequately and 10.2 working days for those who did not recover enough. The good organising of work and the management of job demands - as well as strong work resources, such as job security and experiencing work as significant - increased the likelihood of adequate recovery.

This study supports the view that managing job demands and simultaneously taking care of job resources, as well as job development, are factors that support recovery and employees' work ability, which can be influenced by proactive management while supporting the achievement of company goals in a changing competitive environment.

Keywords: work ability, recovery, job demands, job resources.

Saapunut 17.02.2020

Hyväksytty 20.09.2020

\section{LÄHTEET}

(1) Sedjo RA, Bael D. The Impact of Globalization on the Forest Products Industry. Industry Studies Association Working Paper 2007;36. Luettu 23.1.2020.

https://www.researchgate.net/ publication/277848659

(2) Hetemäki L, Harstela P, Hynynen J. ym. (toim.) Suomen metsiin perustuva hyvinvointi 2015. Katsaus Suomen metsäalan kehitykseen ja tulevaisuuden vaihtoehtoihin. Metlan työraportteja 26. 2006. Luettu 12.5.2020. http://urn.fi/URN:ISBN:978-951-40-2001-8

(3) Näyhä A, Pesonen H-L. Strategic change in the forest industry towards the biorefining business. Technol Forecast Soc Change 2014;81:259-271 https://doi.org/10.1016/j.techfore.2013.04.014

(4) Erlandsson E. The Impact of Industrial Context on Procurement. Management and Development of Harvesting Services: A Comparison of Two Swedish Forest Owners Associations. Forests 2013;4:1171-1198. https://doi:10.3390/f4041171

(5) Müller F, Jaeger D, Hanewinkel M. Digitization in wood supply - A review on how Industry 4.0 will change the forest value chain. Comput
Electron Agric 2019;162:206-218. https://doi.org/10.1016/j.compag.2019.04.002

(6) Kariniemi A. Kuljettajakeskeinen hakkuukonetyön malli - Työn suorituksen kognitiivinen tarkastelu. Akateeminen väitöskirja. Helsingin Yliopiston Metsävarojen käytön laitoksen julkaisuja 38. Helsinki: Yliopistopaino;2006,70-76. http://hdl.handle.net/1975/443

(7) Kollberg, M. Beyond IT and ProductivityEffects of Digitized Information Flows in the Logging Industry. Linköping Studies in Dissertation from the Swedish Science and Technology Research School of Management Dissertation No.1185 and Information Technology (MIT) 2005/EIS-46. Linköping, Sweden: Uni Tryck Linköping; 2005. URN: urn:nbn:se:liu:diva-4150

(8) Nieminen A. Resurssitehokas puunkorjuu. Tapion raportteja nro 5. Helsinki: Tapio Oy; 2015.

(9) Beland Lindahl K, Westholm E. Food, Paper, Wood, or Energy? Global Trends and Future Swedish Forest Use. Forests 2011;2:51-65. https://doi:10.3390/f2010051 
(10) Kekkonen K. "Hyvää vauhtia metsätöille” - Puunkorjuu ja Suomi muutoksessa. Akateeminen väitöskirja. Acta Universitatis Tamperensis 1656.Tampereen yliopisto, yhteiskunta- ja kulttuuritieteiden yksikkö. Tampere: Tampereen Yliopistopaino Oy Juvenes Print; 2011:266,292295. http://urn.fi/urn:isbn:978-951-44-8572-5

(11) Ovaskainen H. Timber harvester operators' working technique in first thinning and the importance of cognitive abilities on work productivity. Academic dissertation. Dissertationes Forestales 79. Faculty of Forest Sciences of the University of Joensuu. Vantaa: The Finnish Society of Forest Science; 2009. https://doi.org/10.14214/df.79

(12) Tervo K. Metsän hiljaiset - Metsätyön rakennemurrosten kolme sukupolvea. Akateeminen väitöskirja. Suomalaisen Kirjallisuuden Toimituksia 1177. Tiede. Helsinki: Suomalaisen Kirjallisuuden Seura; 2008:170,176-179,236-237.

(13) Julkunen R. Uuden työn paradoksit: keskusteluja 2000-luvun työprosessista. Tampere: Vastapaino; 2008.

(14) Järvensivu A, Kokkinen L, Kasvio A. ym. Changes at work - a challenge and an opportunity for well-being at work, careers and the quality of work life. Report for the international evaluation of the Finnish Institute of Occupational Health (FIOH). Helsinki: Finnish Institute of Occupational Health (FIOH); 2014. Luettu 24.7.2019.

https://www.researchgate.net/ publication/268220519

(15) Kariniemi A, Strandström M, AlaLaurinaho A. ym. Työn muutoksen hallinta puuhuoltoprosessissa. Metsätehon katsaus 42.Helsinki: Metsäteho Oy; 2009.

(16) Taskin L, Devos V. Paradoxes from the individualization of human resource management: The case of telework. J Bus Ethics 2005;62:13-24. https://doi.org/10.1007/s10551-005-8710-0

(17) Työolobarometri syksy 2016. Työ- ja elinkeinoministeriön julkaisujatyöelämä-34/2017. Helsinki: Työ- ja elinkeinoministeriö; 2017. http://urn.fi/URN:ISBN:978-952-327-236-1

(18) Työolobarometri 2018 loppuraportti. Työ- ja elinkeinoministeriön julkaisuja-työelämä2019:51. Helsinki: Työ- ja elinkeinoministeriö; 2019.

http://urn.fi/URN:ISBN:978-952-327-454-9

(19) Ukkola S. Koodattu aika. Ristiriitaisuuksien aikakulttuuri tietotyössä. Akateeminen väitöskirja. Acta universitatis Lapponiensis 319. Lapin yliopisto yhteiskuntatieteiden tiedekunta. Rovaniemi: Lapin yliopistopaino; 2016:258. http://urn.fi/URN:ISBN:978-952-484-888-6

(20) Väätäinen K, Ovaskainen H, Ranta P, ym. Hakkuukoneenkuljettajan hiljaisen tiedon merkitys hakkuutulokseen työpistetasolla. Metsäntutkimuslaitoksen tiedonantoja 937. Joensuu: Metla. Joensuun tutkimuskeskus; 2005. http://urn.fi/URN:ISBN:951-40-1950-4
(21) Alasoini T. Digitalisaatio muuttaa työtä - millaista työelämää uudistavaa innovaatiopolitiikkaa tarvitaan? Työpoliittinen Aikakauskirja 2/2015:28-31. Työ- ja elinkeinoministeriö; 2015. Luettu 12.10.2019. http://urn.fi/URN:NBN:fi-fe2016100724889

(22) Alasoini T. Digitalisaatiolla työn uudelleenajatteluun. Millaista tutkimusta ja kehittämistä tarvitaan? Helsinki: Työterveyslaitos, Juvenes Print Tampere; 2018. http://urn.fi/URN:ISBN:9789522618429

(23) Berghäll E, Honkatukia J. Ammattirakenteen muutoksen vaikutukset kansantalouteen. Työ- ja elinkeinoministeriön julkaisujatyöelämä-19/2017:14,26,29-30. Helsinki: Työja elinkeinoministeriö; 2017. http://urn.fi/URN:ISBN:978-952-327-210-1

(24) Häggström C. Human Factors in Mechanized Cut-to-Length Forest Operations. Doctoral Thesis Swedish University of Agricultural Sciences Umeå. Acta Universitatis agriculturae Sueciae 2015:59. Faculty of Forest Sciences Department of Forest Biomaterials and Technology Umeå. Umeå: Arkitektkopia; 2015. http://urn.kb.se/ resolve?urn=urn:nbn:se:slu:epsilon-e-2644

(25) Lindberg A, Hemvik K. How to Recognize Opportunities for Digital Transformation: a Framework for Large \& Established Firms. Master Degree Projection in Innovation and Industrial Management. Master Degree Project No. 2015:40. Gothenburg Sweden: School of business, Economics and law, University of Gothenburg; 2015. http://hdl.handle. net $/ 2077 / 39861$

(26) Demerouti E, Bakker AB, Geurts, SAE. ym. Daily recovery from work-related effort during nonwork time. In S. Sonnentag P, Perrewé \& Ganster $\mathrm{D}$, (Eds.), Currents perspectives on job-stress recovery. Bingley, UK: Emerald; 2009,85-123. https://doi.org/10.1108/S14793555(2009)0000007006

(27) Zijlstra FRH, Sonnentag S. After work is done: Psychological perspectives on recovery from work. Eur J Work Organ Psychol 2006;15:129_ 138. Psychology Press Ltd; 2006. https://doi.org/10.1080/13594320500513855

(28) Geurts SAE, Sonnentag S. Recovery as an explanatory mechanism in the relation between acute stress reactions and chronic health impairment. Scand J Work Environ Health 2006;32:482-492. https://doi: 10.5271/sjweh.1053

(29) Meijman TF, Mulder G. Psychological aspects of workload. Teoksessa: P.J.D., Thierry, H. (toim.) Handbook of Work and Organizational Psychology. Work Psychology; Hove, England: Psychology Press Ltd.; 1998,5-33. http://hdl.handle.net/11370/3adff77b-680b4cba-81d7-ebcd86ba5db5

(30) Siltaloppi M, Kinnunen U. Työkuormituksesta palautuminen: psykologinen näkökulma palautumiseen. Työ ja ihminen 1/2007, kuormittuneisuus I. Aikakauskirja 21. vuosikerta. Helsinki: Työterveyslaitos; 2008,30-41. 
(31) Kinnunen U, Feldt T. Job Characteristics, Recovery Experiences and Occupational Wellbeing: Testing Cross-lagged Relationships across 1 Year. Stress Health 2013;29:369-382. https://doi.org/10.1002/smi.2483

(32) Pennonen M. Recovery from Work Stress, Antecedents, Processes and Outcomes, Academic Dissertation, University of Tampere, School of Social Sciences and Humanities, Finland. Acta Universitatis Tamperensis 1668. Tampere: Tampereen Yliopistopaino Oy - Juvenes Print; 2011. http://urn.fi/urn:isbn:978-951-44-8602-9

(33) Bakker AB, Demerouti E. The Job DemandsResources model: state of the art. JMP 2007;22:309-328. https://doi.org/10.1108/02683940710733115

(34) Bakker AB, \& Demerouti E. Job DemandsResources theory. In C. Cooper \& P. Chen (Eds.), Wellbeing: A complete reference guide. Chichester, UK: Wiley-Blackwell; 2014,37-64. http://dx.doi.org/10.1002/9781118539415. wbwell019

(35) Demerouti E, Bakker AB, Nachreiner F. ym. "The Job Demands-Resources Model of Burnout." J Appl Psychol 2001;86:499-512. https://doi:10.1037//0021-9010.86.3.499

(36) Schaufeli WB, Bakker AB. Job demands, job resources, and their relationship with burnout and engagement. J Organ Behav 2004;25:293315. https://doi.org/10.1002/job.248.

(37) Sonnentag S, Bayer U-V. Switching Off Mentally: Predictors and Consequences of Psychological Detachment From Work During Off-Job Time. J. Occup Health Psychol 2005;10 :393-414. https://doi.org/10.1037/1076-8998.10.4.393

(38) De Raeve L, Jansen NWH, Kant I. Health effects of transitions in work schedule, workhours and overtime in a prospective cohort study. Scand J Work Environ Health 2007; 33:105-113. https://doi:10.5271/sjweh.1113

(39) Ferrie JE, Westerlund H, Virtanen M. ym. Flexible labor markets and employee health. Scand J Work Environ Health Suppl 2008;6:98110. https://www.sjweh.fi/show_abstract. php?abstract_id=1257

(40) Ilmarinen J, Tuomi K, Seitsamo J. New dimensions of work ability. International Congress Series 2005;1280:3-7. https://doi.org/10.1016/j.ics.2005.02.060

(41) Kinnunen U, Siltaloppi M, Mauno S. Työ ja palautuminen. Teoksessa Irtiottoja Työstä: Työkuormituksesta palautumisen psykologia. Kinnunen U. ja Mauno S.(toim.) Tampere: Tampereen yliopistopaino Oy Juvenes Print; 2009,41-51.

(42) Lilley R, Feyer A-M, Kirk P. ym. A survey of forest workers in New Zealand Do hours of work, rest, and recovery play a role in accidents and injury? J Safety Res 2002;33:53-71. https://doi.org/10.1016/S0022-4375(02)00003-8

(43) de Croon EM, Sluiter JK, Frings-Dresen MHW. Need for recovery after work predicts sickness absence A 2-year prospective cohort study in truck drivers. J Psychosom Res 2003;55:
331-339.

https://doi:10.1016/S0022-3999(02)00630-X

(44) Katou AA. How does human resource management influence organizational performance? An integrative approach-based analysis. IJPPM 2017;66:797-821.

https://doi.org/10.1108/IJPPM-01-2016-0004

(45) Koski P, Järvensivu A, Nikkanen R. Organisatoriset käytännöt, yrityksen suorituskyky ja työhyvinvointi - löytyykö yhteyksiä? Hallinnon tutkimus 2014;33:85-101. http://urn.fi/URN:NBN:fi:ELE-1642410

(46) Wood S, Wall T. Work enrichment and employee voice in human resource managementperformance studies. IJHRM 2007;18:13351372.

https://doi.org/10.1080/09585190701394150

(47) Aura O, Ahonen G, Ilmarinen J. Strategisen hyvinvoinnin tila Suomessa 2012. Tutkimusraportti. Pohjola Terveys Oy yhteistyössä Työterveyslaitoksen kanssa. Helsinki: Pohjola Terveys Oy; 2012. http://urn.fi/URN:ISBN 978-952-5848-10-6 (pdf)

(48) Aura O, Ahonen G, Hussi T, Ilmarinen J. Strategisen hyvinvoinnin johtaminen Suomessa 2014. Tutkimusraportti. Helsinki: Pohjola Vakuutus Oy ja Suomen Terveystalo. Työterveyslaitos ja Juhani Ilmarinen Consulting Oy; 2014.

http://urn.fi/URN:[ISBN 978-952-261-490-2 (PDF)]

(49) Elo A-L, Feldt T. Työhyvinvoinnin edistäminen ja kehittäminen. Teoksessa: Työ leipälajina työhyvinvoinnin psykologiset perusteet. Kinnunen U, Feldt T, Mauno S. (toim.). Keuruu: PS-Kustannus, Otava;2005,311-345.

(50) Laine P. Työhyvinvoinnin kehittäminen. Hyvän kehittämisen reunaehtoja tutkimassa. Akateeminen väitöskirja. Turun yliopiston julkaisuja, sarja-c osa-Tom.372. Turun yliopisto University of Turku. Kasvatustieteiden tiedekunta. Turku: Painosalama Oy; 2013. http://urn.fi/URN:ISBN:978-951-29-5570-1

(51) Vanhala S, Tuomi K. HRM, Company Performance and Employee Well-being. Management revue - Socio-Economic Studies, Nomos Verlagsgesellschaft $\mathrm{mbH} \& \mathrm{Co}$ 2006; 17:241-255. https://doi.org/10.5771/0935-9915-2006-3

(52) Kinnunen U, Feldt T. Työkuormituksesta palautuminen. Teoksessa Irtiottoja työstä: Työkuormituksesta palautumisen psykologia. Kinnunen U. ja Mauno S.(toim.) Tampere: Tampereen yliopistopaino Oy Juvenes-Print; 2009,7-27.

(53) Yksilötutka. Työturvallisuuskeskus 2017. Luettu 01.08.2019.

https://ttk.fi/koulutus_ja_kehittaminen/tyokalut_ ja_kehittaminen/yksilotutka.

(54) Gould R, Koskinen S, Seitsamo J. ym. Aineisto ja menetelmät. Työkyvyn osoittimet. Teoksessa: Gould R, Ilmarinen J, Järvisalo J, Koskinen S. (toim.) Työkyvyn ulottuvuudet. Terveys 2000 -tutkimuksen tuloksia. Eläketurvakeskus, 
Kansaneläkelaitos, Kansanterveyslaitos, Työterveyslaitos. Helsinki: Hakapaino Oy; 2006,41-53.

(55) Ilmarinen V, Ilmarinen J, Huuhtanen P. ym. Examining the factorial structure, measurement invariance and convergent and discriminant validity of a novel self-report measure of work ability: work ability - personal radar. Ergonomics 2015; 58:1445-1460. https://doi.org/10.1080/00140139.2015.10051 67

(56) Ahlström L, Grimby-Ekman A, Hagberg M. ym. The work ability index and single-item question: associations with sick leave, symptoms, and health - a prospective study of women on longterm sick leave. Scand J Work Environ Health 2010;36:404-412. https://doi.org/10.5271/sjweh.2917

(57) Ebener M, Hasselborn HM. Validation of Short Measures of Work Ability for Research and Employee Surveys. Int J Environ Res Public Health 2019;16:3386. https://doi:10.3390/ijerph16183386

(58) El Fassi M, Bocquet V, Majery N. ym. Work ability assessment in a worker population: comparison and determinants of Work Ability Index and Work Ability score. BMC Public Health 2013;13:305. https://doi.org/10.1186/1471-2458-13-305

(59) van Schaaijk A, Nieuwenhuijsen K, FringsDresen M. Work Ability and Vitality in Coach Drivers: An RCT to Study the Effectiveness of a Self-Management Intervention during the Peak Season. Int J Environ Res Public Health 2019;16:2214.

https://doi.org/10.3390/ijerph16122214

(60) Sonnentag S. Work, Recovery Activities, and Individual Well-Being: A Diary Study J Occup Health Psychol 2001;6:196-210. https://doi.org/10.1037/1076-8998.6.3.196

(61) Clausen T, Borg V. Job demands, job resources and meaning at work. J Manag Psychol 2011;26:665-681. https://doi.org/10.1108/02683941111181761

(62) Newman DB, Tay L, Diener E. Leisure and Subjective Well-Being: A Model of Psychological Mechanisms as Mediating Factors. J Happiness Stud 2014;15:555-578. https://doi.org/10.1007/s10902-013-9435-x

(63) Kiss P, De Meester M. Need for recovery in ageing workers. International Congress Series 2005;1280:202-207. https://doi.org/10.1016/j.ics.2005.02.056

(64) Kristensen T, Hannerz H, Høgh A. ym. The Copenhagen Psychosocial Questionnaire - tool for the assessment and improvement of the psychosocial work environment. Scand J Work Environ Health 2005;31:438-449. https://doi.org/10.5271/sjweh.948

(65) Gould R, Polvinen A.Työkyky eri ammateissa, toimialoilla. Teoksessa: Työkyvyn ulottuvuudet: Terveys 2000 -tutkimuksen tuloksia. Gould R, Ilmarinen J, Järvisalo J, Koskinen S. (toim.).
Helsinki: Eläketurvakeskus, Kansaneläkelaitos, Kansanterveyslaitos, Työterveyslaitos; 2006,8296.

(66) Roelen CAM, van Rhenen W, Groothoff J. ym. Work ability as prognostic risk marker of disability pension: single-item work ability score versus multi-item work ability index. Scand J Work Environ Health 2014;40:428-431. https://doi.org/10.5271/sjweh.3428

(67) Sonnentag S, Zijlstra FRH. Job characteristics and off-job activities as predictors of need for recovery, well-being, and fatigue. J Appl Psychol 2006;91:330-350.

https://doi.org/10.1037/0021-9010.91.2.330

(68) Boström M, Sluiter JK, Hagberg M. ym. Opportunities for recovery at work and excellent work ability - a cross-sectional population study among young workers. BMC Public Health 2016;16:985. https://doi.org/10.1186/s12889-016-3654-0

(69) Härmä M. Workhours in relation to stress, recovery and health. Scand J Work Environ Health 2006;32:502-514. https://doi.org/10.5271/sjweh.1055

(70) Bamberger SG, Larsen A, Vinding AL. ym. Assessment of work intensification by managers and psychological distressed and non-distressed employees: a multilevel comparison. Ind Health 2015;53:322-331. https://doi.org/10.2486/indhealth.2014-0176

(71) Pencavel J. Recovery from Work and the Productivity of Working Hours. Economica 2016;83:545-563. https://doi.org/10.1111/ ecca. 12206

(72) Hakanen J. Työuupumuksesta työn imuun: työhyvinvointitutkimuksen ytimessä ja reunaalueilla. Työ ja ihminen Tutkimusraportti 27. Helsinki: Työterveyslaitos. Tampereen yliopistopaino; 2004. http://urn.fi/URN:9789522618153

(73) Pahkin K. Staying well in an unstable world of work - Prospective cohort study of the determinants of employee well-being. Akateeminen väitöskirja. People and Work Research Reports 107. Helsinki: Finnish Institute of Occupational Health. Suomen Yliopistopaino Oy - Juvenes Print; Tampere 2015. http://urn.fi/URN:ISBN:978-952-261-515-2

(74) Gellerstedt S. Operation of the Single-Grip Harvester: Motor-Sensory and Cognitive Work. Int J For Eng 2002;13:35-47. https://doi.org/10.1080/14942119.2002.10702 461

(75) Patten CJD, Kircher A, Östlund J. ym. Driver experience and cognitive workload in different traffic environments. Accid Anal Prev 2006;38:887-894. https://doi.org/10.1016/j.aap.2006.02.014

(76) Arnold KA, Turner N, Barling J. ym. Transformational leadership and psychological well-being: The mediating role of meaningful work. J Occup Health Psychol 2007;12:193-203. https://doi.org/10.1037/1076-8998.12.3.193 
(77) Fairlie P. Meaningful Work, Employee Engagement, and Other Key Employee, Outcomes: Implications for Human Resource Development. Advances in Developing Human Resources. SAGE Publications 2011;13:508-525. https://doi.org/10.1177/1523422311431679

(78) Geldenhuys M, Laba K, Venter CM. Meaningful work, work engagement and organisational commitment. SA j ind Psychol 2014;40:1-10. https://doi.org/10.4102/sajip.v40i1.1098

(79) Nielsen K, Randall R, Yarker J. ym.The effects of transformational leadership on followers' perceived work characteristics and psychological well-being: A longitudinal study. Work Stress 2008;22:16-32.

https://doi.org/10.1080/02678370801979430

(80) Siltaloppi M, Kinnunen U, Feldt T. Recovery experiences as moderators between psychosocial work characteristics and occupational well-being. Work Stress 2009;23:330-348. https://doi.org/10.1080/02678370903415572

(81) Sonnentag S, Fritz C. The Recovery Experience Questionnaire: Development and validation of a measure for assessing recuperation and unwinding from work. J Occup Health Psychol 2007;12:204-221. https://doi.org/10.1037/1076-8998.12.3.204

(82) Nieuwenhuis M, Lyons M. Health and Safety Issues and Perception of Forest Harvesting Contractors in Ireland. Int J For Eng 2002;13:69-76. https://doi.org/10.1080/14942119.2002.10702 464
(83) Suomen Yrittäjät. Työkyky ja -hyvinvointikysely. Luettu 14.12.2018 https://www.yrittajat.fi/ suomenyrittajat / tutkimukset/muut-tutkimukset /tyokyky-ja-hyvinvointikysely-3197532010.

(84) Ylimäki R. Väätäinen K, Lamminen, S. ym. Kuljettajaa opastavien järjestelmien tarve ja hyötypotentiaali koneellisessa puunkorjuussa. Metlan työraportteja 224.Vantaa: Metla; 2012. Luettu 30.1.2020. http://urn.fi/URN:ISBN:978-951-40-2352-1

\section{Hannu Pursio}

TtM, Väitöskirjatutkija

Tampereen yliopisto

Yhteiskuntatieteiden tiedekunta, terveystieteet

AnNa Siukola

TtT, Projektipäällikkö

Tampereen yliopisto

Lääketieteen ja terveysteknologian tiedekunta

Heini Huhtala

FM, Yliopisto-opettaja

Tampereen yliopisto

Yhteiskuntatieteiden tiedekunta, terveystieteet

Clas-HÅKAN NYgÅRD

FT, Professori

Tampereen yliopisto

Yhteiskuntatieteellinen tiedekunta, terveystieteet 